\title{
Doğu Akdeniz Bölgesindeki Krom Maden Alanı Topraklarında Azot Mineralizasyonu
}

\author{
Nacide KIZILDAĞ* \\ Çukurova Üniversitesi, Merkezi Araștırma Laboratuvarı, 01330, Adana
}

*Sorumlu yazar e-posta (Corresponding author e-mail) : nkizildag@cu.edu.tr

Geliș tarihi (Received) : 17.01.2017

Kabul tarihi (Accepted): 10.03.2017

\section{Öz}

Kromun ( $\mathrm{Cr}$ ) endüstrideki yaygın kullanımına bağlı olarak çeșitli çevresel ortamlarda ciddi bir kirletici haline geldiği ve toprak mikroorganizmalarına karșı son derece toksik etki gösterdiği bilinmektedir. Buna göre kroma uzun süre maruz kalmıș ekosistemlerde toprak mikroorganizmalarının fonksiyonlarının bilinmesi çok önemli bir yer tutmaktadır. Bu bağlamda Aladağ' da (Adana) krom maden ocağına yakın ve ocaktan etkilenmemiș 3 farklı alandan (Bozluk, Kızılyüksek ve Yanıkçam) alınan cevherli ve cevhersiz toprakların azot mineralizasyonlarını kıyaslamak ve kromun mikroorganizmalara olası etkilerini ortaya koymak amaçlanmıștır. Toprakların azot mineralizasyonu $\left(\mathrm{NH}_{4}+-\mathrm{N}, \mathrm{NO}_{3}-\mathrm{N}\right)$ Parnas-Wagner metodu ile 42 gün boyunca (11., 26. ve 42. gün) $28^{\circ} \mathrm{C}$ ve sabit nemde belirlenmiștir. Yanıkçam lokasyonu haricinde cevherli toprakların toplam $\mathrm{Cr}$ içeriği cevhersiz topraklara göre daha yüksek bulunmuștur (309, $59 \mathrm{mg} \mathrm{kg}^{-1}$ ). Her üç lokasyonda da $\mathrm{Cr}$ ilave edilen ve edilmeyen cevhersiz toprakların azot mineralizasyon oranları, cevherli topraklardan daha yüksek bulunmuștur. En yüksek mineralleșme oranı $\mathrm{Cr}$ ilave edilmeyen cevhersiz Kızılyüksek toprağında (\% 1.73), en düșük ise yine $\mathrm{Cr}$ ilavesi olmayan cevherli Yanıkçam (\% 0.36) toprağında gözlenmiștir. Bu çalıșmadan elde edilen sonuçlara dayanarak, amonyak ve nitrat bakterilerinin kromdan etkilendiğini söylemek mümkündür.

Anahtar Kelimeler: Krom, azot mineralizasyonu, maden ocağı, toksisite, Aladağ

\section{Nitrogen Mineralization in Soils of Chromium Mine Area in the East Mediterranean Region}

\footnotetext{
Abstract

It is known that chromium became a serious pollutant in various environmental due to its common use in industry and that it is highly toxic effect for soil microorganisms. For this reason, it is important to know the functioning of soil microorganism in ecosystesms which are exposed to chromium for a long time. In this context, it was aimed to compare nitrogen mineralization of contamined and uncontamined soils which were in 3 different regions (Bozluk, Kızllyüksek and Yanıkçam) in Aladağ (Adana) near mine but not effected of it and to reveal possible effects of chromium on microorganism. Nitrogen mineralization of soils $\left(\mathrm{NH}_{4}+-\mathrm{N}_{1} \mathrm{NO}_{3}-\mathrm{N}\right)$ was determined by the Parnas-Wagner method over 42 days $\left(11^{\text {th }}, 26^{\text {th }}\right.$, and $42^{\text {nd }}$ days $)$ at $28^{\circ} \mathrm{C}$ and under constant moisture. The total $\mathrm{Cr}$ content of contamined soils is higher than uncontamined soils except for Yanıçam region $1309,59 \mathrm{mg} \mathrm{kg}$ '). In each place, mineralization rates of chromium added contamined or uncontamined soils were measured higher than the soils which were contamined. The maximum mineralization rate was observed in uncontamined soils of Kızlyüksek (1.73\%) which were not added $\mathrm{Cr}$, the minimum rate was in the soils of contamined soils of Yanıkçam which were also not added $(0.36 \%)$. Based on the results obtained from the findings of this study, it is possible that ammonium and nitrate bacteria was affected by chromium.
} 
Key Words: Chromium, nitrogen mineralization, Mining, toxicity, Aladağ

\section{Gíriș}

Antropojenik faaliyetler sonucu toprakların ağır metallerce kirlenmesi tüm dünyada ciddi bir çevresel sorun haline gelmiștir. Madencilik, metalli cevherlerin, hurda metallerin eritilmesi ve ișlenmesi, kentsel atıklar, hem biosit (pestisit), hem de gübre uygulamaları ağır metallere bağlı toprak kirliliğinin ana kaynağını olușturmaktadırlar (Kebir ve Bouhadjera, 2011 ). Toprak mikrobiyal populasyonu bu ağır metallerden kaynaklanan büyük bir baskı altında olup (Chaudhary ve ark., 1996; Obbard, 2001) kirleticilerin olumsuz etkilerini ilk olarak algılayan ve doğru yansıtan canlılardır. Bu populasyonu olușturan canlıların potansiyeli ve çeșitliliği çevredeki kirlilik derecesini değerlendirmede önemli bir gösterge olarak kullanılabilmektedir (Sani ve ark., 2003; Utgikar ve ark., 2004; Ahmad ve ark., 2005). Ağır metallerin yüksek konsantrasyonları mikroorganizma populasyonu ve aktivitelerini değiștirerek toprak verimliliğini olumsuz etkilemektedir (Friedlova, 2010).

Krom (Cr) toprak kirliliğine sebep olan belli bașlı ağır metaller arasında yer almaktadır (Lenart ve Wolny- Koladka, 2013). Toprak mikroorganizmalarına karșı son derece toksik etki gösteren bir metal olup endüstride yaygın kullanımına bağlı olarak, çevresel ortamlarda ciddi bir kirletici haline gelmiștir. Krom doğada $\mathrm{Cr}$ (III) ve $\mathrm{Cr}(\mathrm{VI})$ formunda bulunmaktadır (Apte ve ark., 2006). Kromat endüstrisi, topraklar için krom kirliliği açısından tehlike olușturmaktadır (Alcântara ve ark., 2007). Bu nedenle uzun süre kroma maruz kalmıș topraklarda mikroorganizma fonksiyonlarındaki değișimin araștırılması önemli olmaktadır. Yapılan bir çalıșma, toprağa artan dozlarda (0-100 mg/ kg) uygulanan kromun, toprağın mikroorganizma ve enzim aktivitesini önemli ölçüde düșürdüğünü göstermiștir (Dotaniya ve ark., 2017).

Toprakta, ana kayada ve havada serbest ve bağlı azotun bulunuș miktarları çok yüksek olabilmesine karșın kullanılabilirliği mikroorganizma faaliyetleri sonucu mümkün olabilmektedir (Tecimen ve Sevgi, 2008). Topraktan azot alınabilirliği toprak kalitesinin önemli bir göstergesidir (Ünver, 2007). Azot mineralizasyonu, toprak organik maddesindeki kompleks azotlu bileșiklerin ayrıșma ve transformasyonları sonucu basit inorganik azot formlarına dönüșmesi olarak tanımlanmaktadır. Biyokimyasal olan bu süreç toprak organik maddesinin kalitesi, mikrobiyal biyomas, mikrobiyal etkinlik, toprak sıcaklığı ve nemi gibi faktörler ve diğer ortam koșulları tarafından kontrol edilmektedir (Ünver, 2007).

Bu çalıșmanın amacı, Aladağ (Adana) krom maden ocağına yakın ve ocaktan etkilenmemiș alanlardan (Bozluk, Kızılyüksek ve Yanıkçam) alınan cevherli ve cevhersiz topraklarda potansiyel azot mineralizasyonunu kıyaslamak ve kromun mikroorganizmalara olası etkilerini ortaya koymaktır.

\section{MATERYAL VE YÖNTEM}

Adana ili Aladağ ilçesinde bulunan krom maden ișletmesi yakınlarındaki Bozluk, Kızılyüksek ve Yanıkçam mevkileri örneklik alan olarak

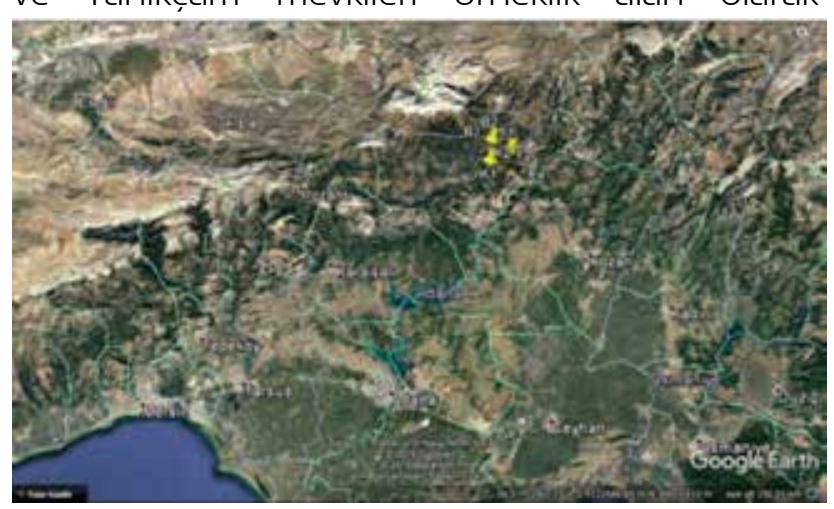

Șekil 1. Örnek alım yerlerinin uydu görüntüsü (1: Cevherli, 2: Cevhersiz)

Figure 1. Satellite view of sample locations

seçilmiștir (Șekil 1).

Her üç lokasyonda kromla kontamine olmuș ve olmamıș (cevherli ve cevhersiz) alanlardan $0-20 \mathrm{~cm}$ derinliğinden toprak örnekleri alınmıștır. Örneklik alanların koordinatları Çizelge 1' de verilmiștir.

Topraklar laboratuvarda kurutulup 2 mm' lik elekle elenerek analizlere hazır hale getirilmiștir. Toprakların bünye tipi hidrometre yöntemi ile (Bouyoucos, 1951), toprak pH'sı 1:2.5'lik topraksu karıșımında InoLab pH metresi ile (Jackson, 1958), kireç içeriği (\%) Scheibler kalsimetresi ile (Allison ve Moddie, 1965), tarla kapasitesi (TK, \%) 1/3 atmosferlik basınçlı vakum pompası ile belirlenmiștir (Demiralay, 1993). Toprakların C içeriği (\%C) Anne metodu (Duchaufour, 1970), toplam $\mathrm{N}$ içeriği (\%N) Kjeldahl metodu ve toplam 
Çizelge 1. Örneklik alanların koordinatları (X ve Y:Koordinat, Z:Denizden Yükseklik)

Table 1. Coordinates of the sampling areas (X and Y:Coordinate, Z:Altitude)

\begin{tabular}{lccc}
\hline Lokasyon & X & Y & Z \\
\hline Bozluk-Cevherli & 4171621.48 & 713339.48 & 1161.04 \\
Bozluk-Cevhersiz & 4171912.92 & 713336.87 & 1172.73 \\
Kızılyüksek-Cevherli & 4165312.89 & 715015.89 & 1218.32 \\
Kızılyüksek-Cevhersiz & 4165057,09 & 714498.87 & 1264.14 \\
Yanıkçam-Cevherli & 4170015.91 & 719005.97 & 1545.39 \\
Yanıkçam-Cevhersiz & 4169808.46 & 719351.17 & 1563.12 \\
\hline
\end{tabular}

$\mathrm{Cr}$ içerikleri ise ICP-OES ile yaș yakma yöntemine (Reisenauer, 1982) göre belirlenmiștir.

Azot mineralizasyonu için toprak örnekleri 750 ml'lik inkübasyon kavanozlarına konulup tarla kapasitelerinin \%80'i oranında nemlendirilmiștir. Hava girișini sağlamak için kavanozların ağzı ince bir bez ile kapatılıp $28^{\circ} \mathrm{C}$ de 42 gün boyunca inkübasyona bırakılmıștır. 11., 26. ve 42. günler sonunda topraklar, $200 \mathrm{ml} 1.0 \mathrm{~N}$ $\mathrm{CaCl}_{2}$ çözeltisi ile 1 saat karıștırılıp çalkalanmıș ve süzüldükten sonra süzükte Parnas-Wagner metoduna göre Mineral Azot $\left(\mathrm{NH}_{4}{ }^{+}-\mathrm{N}, \mathrm{NO}_{3}{ }^{-} \mathrm{N}\right)$ içerikleri belirlenmiștir (Lemée, 1967; Gökçeoğlu, 1979). Krom madeni alanından alınan cevherli ve cevhersiz topraklar kontrol grubu olarak direk inkübasyona bırakılmıștır. Ayrıca kontrol grubu dıșında, kromun etkisini kıyaslamak için ayrı bir grup olarak in vitro toprakların toplam $\mathrm{Cr}$ içeriğine eș değer oranda $\mathrm{Cr}$ içeren $\mathrm{K}_{2} \mathrm{Cr}_{2} \mathrm{O}_{7}$ karıștırılıp azot mineralizasyonları incelenmiștir. Dolayısıyla bu grupta, toplam $\mathrm{Cr}$ içeriğine eș değer oranda $\mathrm{Cr}$ içeren $\mathrm{K}_{2} \mathrm{Cr}_{2} \mathrm{O}_{7}$ ilavesinden sonra tüm toprakların Cr içeriği bașlangıca göre 2 kat olmuștur.

Araștırma verilerinin istatistiksel analizi SPSS 21.0 paket programı ile yapılmıștır. Tüm örneklerin analiz sonuçları 3 tekrarlı olarak ortalama \pm standart hata olarak belirlenmiș, bu sonuçların aralarındaki farklar Tukey HSD ile ortaya konmuș ve çizelge ve șekillerde sunulmuștur. Tüm istatistik analiz için önem düzeyi $P \leq 0.05$ olarak alınmıștır.

\section{BULGULAR VE TARTIȘMA}

Toprakların fiziksel ve kimyasal analiz sonuçları istatistiksel olarak değerlendirilmiș, ortalama ve standart hata değerleri Çizelge 2' de verilmiștir. Her üç lokasyonun tüm toprakları kumlu killi tınlı (SCL) olup tarla kapasiteleri 21.15 ile 28.35 (\%) arasında ve genel olarak cevhersiz topraklarda daha yüksek bulunmuștur. Tüm toprakların $\mathrm{pH}^{\prime}$ ları ise hafif alkali olup aralarında istatistiksel olarak fark gözlenmemiștir (P>0.05), (Çizelge 2).

Çizelge 2. Bozluk, Kızılyüksek ve Yanıkçam topraklarının bazı fiziksel ve kimyasal özellikleri

Table 2. Soils of Bozluk, Kızılyüksek and Yanıkçam some physical and chemical properties

\begin{tabular}{lrrrrrr}
\hline \multicolumn{7}{c}{ Bölgeler } \\
\hline Analizler & Bozluk & Kızlyüksek & Yanıkçam & Bozluk & Kızllyüksek & \multicolumn{1}{c}{ Yanıkçam } \\
\hline Kum(\%) & $61,72 \pm 0,91$ & $71,36 \pm 0,49$ & $60,54 \pm 0,33$ & $56,57 \pm 1,19$ & $62,58 \pm 0,95$ & $65,50 \pm 0,69$ \\
Silt(\%) & $18,24 \pm 0,62$ & $13,90 \pm 0,26$ & $15,09 \pm 0,89$ & $16,40 \pm 0,67$ & $13,24 \pm 0,74$ & $11,72 \pm 1,00$ \\
Kil(\%) & $20,71 \pm 0,31$ & $15,84 \pm 051$ & $23,93 \pm 0,88$ & $22,29 \pm 0,50$ & $21,96 \pm 1,23$ & $20,90 \pm 0,22$ \\
Tekstür tipi & & \multicolumn{5}{c}{ Kumlu Killi Tınlı(SCL) } \\
TK(\%) & $24,40 \pm 1,18$ & $21,15 \pm 0,92$ & $27,60 \pm 2,25$ & $28,35 \pm 2,10$ & $25,80 \pm 1,25$ & $24,50 \pm 0,88$ \\
PH & $7,38 \pm 0,01$ & $7,45 \pm 0,02$ & $7,41 \pm 0,02$ & $7,38 \pm 0,02$ & $7,39 \pm 0,03$ & $7,40 \pm 0,03$ \\
C(\%) & $2,10 \pm 0,05$ & $1,94 \pm 0,10$ & $2,63 \pm 0,09$ & $1,77 \pm 0,05$ & $1,95 \pm 0,10$ & $1,34 \pm 0,04$ \\
N(\%) & $0,18 \pm 0,00$ & $0,18 \pm 0,00$ & $0,20 \pm 0,01$ & $0,16 \pm 0,01$ & $0,18 \pm 0,01$ & $0,15 \pm 0,01$ \\
C/N & $11,89 \pm 0,05$ & $10,62 \pm 0,70$ & $12,92 \pm 0,31$ & $11,12 \pm 0,28$ & $10,83 \pm 0,10$ & $8,74 \pm 0,41$ \\
Cr(ppm) & $229,17 \pm 0,02$ & $296,10 \pm 0,01$ & $309,59 \pm 0,01$ & $205,51 \pm 0,40$ & $213,43 \pm 0,16$ & $258,07 \pm 0,24$ \\
\hline
\end{tabular}


Çizelge 3. Bozluk, Kızılyüksek ve Yanıkçam topraklarının azot mineralizasyonları (42 gün)

Table 3. Nitrogen mineralization the soils of Bozluk, Kızılyüksek and Yanıkçam (42 days)

\begin{tabular}{|c|c|c|c|c|c|c|c|c|c|}
\hline \multicolumn{4}{|c|}{$\mathrm{HN}_{4}{ }^{+}-\mathrm{N}$} & \multicolumn{5}{|c|}{$\mathrm{NO}_{3}-\mathrm{N}$} & \multirow{2}{*}{$\begin{array}{c}N \text { min } \\
(\%)\end{array}$} \\
\hline & & & 11. gün & 26. gün & 42. gün & 11.gün & 26. gün & 42. gün & \\
\hline \multirow{6}{*}{ İlavesiz } & \multirow{2}{*}{ Bozuk } & Cevhersiz & $8,44 \pm 0,23$ & $7,18 \pm 0,22$ & $6,63 \pm 0,32$ & $11,01 \pm 0,10$ & $12,06 \pm 0,14$ & $19,06 \pm 0,14$ & $1,61 \pm 0,02$ \\
\hline & & Cevherli & $7,27 \pm 0,12$ & $6,73 \pm \pm 0,16$ & $5,61 \pm 0,38$ & $10,12 \pm 0,11$ & $9,72 \pm 0,10$ & $12,99 \pm 0,20$ & $1,05 \pm 0,03$ \\
\hline & \multirow{2}{*}{ Kızılyüksek } & Cevhersiz & $9,20 \pm 0,19$ & $8,78 \pm 0,11$ & $6,00 \pm 0,15$ & $14,76 \pm 0,23$ & $20,88 \pm 0,12$ & $25,76 \pm 1,23$ & $1,73 \pm 0,07$ \\
\hline & & Cevherli & $5,02 \pm 0,05$ & $4,62 \pm 0,02$ & $4,8 \pm 0,06$ & $8,25 \pm 0,41$ & $6,47 \pm 0,25$ & $4,50 \pm 0,42$ & $0,52 \pm 0,03$ \\
\hline & \multirow{2}{*}{ Yanıkçam } & Cevhersiz & $7,14 \pm 0,20$ & $6,32 \pm 0,22$ & $5,33 \pm 0,30$ & $11,06 \pm 0,21$ & $10,82 \pm 0,42$ & $17,06 \pm 0,82$ & $1,46 \pm 0,04$ \\
\hline & & Cevherli & $6,25 \pm 0,21$ & $5,38 \pm 0,13$ & $5,92 \pm 0,24$ & $4,33 \pm 0,16$ & $3,83 \pm 0,17$ & $1,38 \pm 0,26$ & $0,36 \pm 0,00$ \\
\hline \multirow{6}{*}{$\begin{array}{c}\mathrm{K}_{2} \mathrm{Cr}_{2} \mathrm{O}_{7} \\
\text { Illaveli }\end{array}$} & \multirow{2}{*}{ Bozluk } & Cevhersiz & $9,24 \pm 0,15$ & $8,32 \pm 0,29$ & $7,44 \pm 0,31$ & $11,84 \pm 0,54$ & $14,34 \pm 0,41$ & $18,26 \pm 0,63$ & $1,61 \pm 0,04$ \\
\hline & & Cevherli & $7,36 \pm 0,18$ & $9,13 \pm 0,24$ & $9,67 \pm 0,26$ & $6,35 \pm 0,24$ & $8,12 \pm 0,32$ & $11,44 \pm 0,64$ & $1,19 \pm 0,05$ \\
\hline & \multirow{2}{*}{ Kızılyüksek } & Cevhersiz & $6,98 \pm 0,24$ & $6,22 \pm 0,41$ & $5,98 \pm 0,55$ & $10,05 \pm 0,41$ & $8,78 \pm 0,19$ & $13,38 \pm 0,59$ & $1,05 \pm 0,05$ \\
\hline & & Cevherli & $8,95 \pm 0,11$ & $6,04 \pm 0,32$ & $12,01 \pm 0,55$ & $8,52 \pm 0,34$ & $7,12 \pm 0,24$ & $3,58 \pm 0,60$ & $0,87 \pm 0,04$ \\
\hline & \multirow{2}{*}{ Yanıkçam } & ersiz & $11,21 \pm 0,25$ & $10,08 \pm 0,52$ & $15,42 \pm 0,65$ & $6,48 \pm 0,30$ & $5,66 \pm 0,18$ & $6,58 \pm 0,51$ & $1,44 \pm 0,04$ \\
\hline & & Cevherli & $5,35 \pm 0,20$ & $8,14 \pm 0,11$ & $7,08 \pm 0,12$ & $8,71 \pm 0,12$ & $6,28 \pm 0,24$ & $3,69 \pm 0,31$ & $053 \pm 0,02$ \\
\hline
\end{tabular}

Karbon içeriği en yüksek cevherli Yanıkçam $(\%$ 2.63), en düșük ise Yanıkçam cevhersiz topraklarında (\% 1.34) gözlenmiș olup aralarındaki fark anlamlıdır $(P<0.001)$. Tüm toprakların azot içerikleri ise 0.15-0.20 arasında olup cevherli topraklarda daha yüksek bulunmuștur. C/N oranları ise 8.74-12.92 arasındadır (Çizelge 2).

Toplam Cr içeriği en yüksek Yanıkçam cevherli topraklarında (309. $59 \mathrm{mg} \mathrm{kg}^{-1}$ ), en düșük ise Bozluk cevhersiz topraklarında $(205.51$ mg $\mathrm{kg}^{-1}$ ) saptanmıș olup aralarında anlamlı fark bulunmuștur ( $P<0.001$ ) (Çizelge 2$)$.

Her üç alanın krom ilave edilmeyen topraklarının ilk 11. günlük sonuçlarına göre en yüksek $\mathrm{NH}_{4}-\mathrm{N}$ (9.20 mg kg-1) ve NO3-N (14.76 mg kg-1) üretimi cevhersiz Kızılyüksek toprağında gözlenmiștir. 26. günde en yüksek amonifikasyon 18.78 mg $\mathrm{kg}^{-1}$ ), en yüksek nitrifikasyon cevhersiz Kızılyüksek (20.88 $\mathrm{mg} \mathrm{kg}^{-1}$ ) topraklarında gerçekleșmiștir. Aktif vejetasyona denk gelen 42. gün sonuçları incelendiğinde en yüksek NH4-N üretimi cevhersiz Bozluk toprağında $\left(6.63 \mathrm{mg} \mathrm{kg}^{-1}\right)$, en yüksek $\mathrm{NO}_{3}-\mathrm{N}$ üretimi ise cevhersiz Kızılyüksek $(25.76 \mathrm{mg}$ $\mathrm{kg}^{-1}$ ) toprağında meydana gelmiștir (Çizelge 3).

In vitro olarak $\mathrm{K}_{2} \mathrm{Cr}_{2} \mathrm{O}_{7}$ ilave edilen her üç Iokasyon topraklarının 11., 26. ve 42. günleri arasında en yüksek $\mathrm{NH}_{4}-\mathrm{N}$ içeriği cevhersiz Yanıkçam (sırasıyla 11.21, 10.08 ve $15.42 \mathrm{mg} \mathrm{kg}^{-1}$ ) topraklarında olup aralarında istatistiksel olarak anlamlı fark bulunmuștur $(P<0.05)$. 11., 26. ve
42. günleri arasında en yüksek nitrifikasyon ise cevhersiz Bozluk (11.84, 14.34 ve $\left.18.26 \mathrm{mg} \mathrm{kg}^{-1}\right)$ topraklarında gerçekleșmiștir (Çizelge 3).

Toprakların azot mineralizasyon oranları kıyaslandığında, hem lokasyon hem de cevherli ve cevhersiz topraklardan kaynaklanan anlamlı farklar ortaya çıkmıștır (Tablo 2). Her üç lokasyonda da $\mathrm{Cr}$ ilave edilen ve edilmeyen cevhersiz toprakların azot mineralizasyon oranları, cevherli topraklardan daha yüksek bulunmuștur. En yüksek mineralleșme oranı $\mathrm{K}_{2} \mathrm{Cr}_{2} \mathrm{O}_{7}$ ilave edilmeyen cevhersiz Kızılyüksek toprağında $1 \%$ 1.73), en düșük ise yine ilavesiz cevherli Yanıkçam (\% 0.36) toprağında gözlenmiștir.

Toprak tipi, anamateryalin kökeni, organik maddenin kalitesi (C/N oranı, lignin içeriği) ve toprağın ağır metal içeriği gibi ortam koșulları biyokimyasal bir süreç olan azot mineralizasyonunu etkilemektedir (Ünver, 2007). Krom içeriklerine göre mineralizasyon oranları değerlendirildiğinde en yüksek krom (309.59 m mg kg-1 $\mathrm{Cr}^{\prime}$ da \% 0.36) miktarına sahip toprağın azot mineralizasyonu ile en düșük oran (205.51 mg kg-1 $\mathrm{Cr}^{\prime}$ da \% 1.61 ) arasında 4.47 kat fazlalık bulunmaktadır. Krom miktarı azaldıkça azot mineralizasyon oranının arttığını söylemek mümkündür. Tüm topraklar arasında en düșük azot mineralizasyon oranı cevherli Yanıkçam toprağında saptanmıș olup, bu durum toprağın yüksek $\mathrm{Cr}$ içeriği 1309.59 $\mathrm{mg} \mathrm{kg}$ ) ile açıklanabilir. Bu lokasyondaki $\mathrm{Cr}$ konsantrasyonunun topraktaki amonyak ve nitrat 
bakterilerinin faaliyetlerini inhibe edici bir etkiye neden olduğu anlașılmaktadır. Krom ilavesinin cevhersiz topraklarda azot mineralizasyon oranlarını çok olumsuz etkilemediği, buna karșlık cevherli topraklarda arttırdığı gözlenmektedir. Aslında burada krom kaynağı olarak toprağa karıștırılan $\mathrm{K}_{2} \mathrm{Cr}_{2} \mathrm{O}_{7}^{\prime}$ nın içerdiği bol oksijenin $\mathrm{NO}_{3}$ olușumunu arttırarak azot mineralizasyon oranlarının yüksek çıkmasına neden olduğu, hatta bu topraklara adapte olmuș mikroorganizmaların krom varlığına özel bir tolerans geliștirdiği de düșünülebilir. Buna benzer olarak Walpola ve ark. (2011)' da, Cd ilave edilmiș toprakların azot mineralizasyonunu kontrol toprağına göre daha düșük bulmușlardır.

Bu çalıșma sonucuna göre Kızılyüksek ve Yanıkçam topraklarındaki mikroorganizmaların kroma daha hassas olduklarını söylemek mümkündür. Dotaniya ve ark. (2017)' da yaptıkları çalıșmada artan $\mathrm{Cr}$ dozlarının mikroorganizma ve enzim faaliyetini düșürdüğünü saptamıștır. Hem $\mathrm{K}_{2} \mathrm{Cr}_{2} \mathrm{O}_{7}$ ilaveli, hem de ilavesiz Bozluk topraklarında mineralizasyon oranları birbirine yakın bulunmuștur. Buna göre 205, 51 (BozlukCevhersiz) ve 229, 17 (Bozluk-Cevherli) mg kg' 'lik $\mathrm{Cr}$ içeriklerinin bu bölge toprağı için çok olumsuz etki yapmadığı gözlenmiștir.

Mikroorganizma ve ağır metal ilișkisini etkileyen en önemli parametreler toprak pH'sı, kilin kalitesi ve miktarı, metal iyonları ve inorganik bileșiklerdir (Nwuche ve Ugoji, 2008). Toprak pH' sı topraktaki metallerin çözünebilirliği, kullanılabilirliği ve toksisitesini büyük ölçüde etkilemektedir (Baath ve Arnebrant, 1994; Martyn ve Skwaryło-Bednarz 2005). Wang ve ark. (2007) asidik karakterli topraklarda çok düșük metal konsantrasyonlarının bile toprak mikroorganizmalarını olumsuz etkilediğini tespit etmișlerdir.

Dünya topraklarının 5-3000 $\mathrm{mg} \mathrm{kg}^{-1}$ arasında $\mathrm{Cr}$ içerdiği bilinmektedir (Allaway, 1968). Bu çalıșma topraklarının Cr içerikleri düșük bulunmuș olup bu topraklarda yașayan mikroorganizmaların özel bir mekanizma geliștirerek doğal dengeyi sağlayıp korudukları sonucuna varılabilir.

\section{SONUC̣LAR}

Araștırma sonuçlarına göre krom varlığının toprak özelliklerine bağlı olarak toprak dengesini olumsuz yönde etkilediği ve bu etkinin toprak mikroorganizmaları tarafından tolere edilebildiğini söylemek mümkündür. Bu doğrultuda azot mineralizasyonunun topraktaki ağır metal kirliliğinde bir gösterge olabileceği söylenebilir.

\section{KAYNAKLAR}

Ahmad I, Hayat S, Ahmad A, Inam A, Samiullah I (2005). Effect of heavy metal on survival of certain groups of indigenous soil microbial population. Journal of Applied Sciences and Environmental Management, 9: 115-121.

Alcântara M K, Neto V A, Camargo O A, Cantarella H (2007). Nitrogen mineralization in soils treated with tannery sludge. Pesquisa Agropecuária Brasileira, 40: 547-555

Allaway W H (1968). Agronomic control over the environmental cycling of trace elements. Advances in Agronomy, 20: 235-274.

Allison LE, Moodie CD (1965). Carbonate. In: C.A. Black et al (ed.) Methods of Soil Analysis, Part 2. Agronomy., Am. Soc. Of Agron., Inc., Madison, Wisconsin, U.S.A. 9: 1379-1400.

Apte A D, Tare V, Bose P (2006). Extent of oxidation of $\mathrm{Cr}(\mathrm{III})$ to $\mathrm{Cr}(\mathrm{VI})$ under various conditions pertaining to natural environment. Journal of Hazardous Materials, 164-174.

Bààth E, Arnebrant K (1994). Growth-rate and response of bacterial communities to $\mathrm{pH}$ in limed and ash treated forest soils. Soil Biology and Biochemistry, 26: 995-1001.

Bouyoucos G S (1951). A recalibration of the hydrometer for mohing mechanical analysis of soil. Agronomy Journal, 43: 434-438.

Chaudhary A M, MacGrath S P, Knight B P, Johnson D $L$, Jones K C (1996). Toxicity of organic compounds to the indigenous population of R. leguminosorum bv. trifolii in soil. Soil Biology and Biochemistry, 28: 1483-1487.

Demiralay i (1993). Toprak Fiziksel Analizleri. Atatürk Üniversitesi Ziraat Fakültesi Yayınları No: 143, sf: 78-89, Erzurum.

Dotaniya M L, Rajendiran S, Meena $V$ D, Saha J K, Vassanda Coumar M, Kundu S, Patra A K (2017). Influence of chromium contamination on carbon mineralization and enzymatic activities in vertisol. Agricultural Research, 6: 91-96.

Duchaufour P (1970). Precis de Pedologie. Masson et Cle, Editeurs, p: 435-437, Paris.

Friedlova M (2010). The influence of heavy metals on soil biological and chemical properties. Soil and Water Research, 5(1):21-27

Gökçeoğlu M (1979). Bazı bitki organlarındaki azot, fosfor ve potasyumun bir vejetasyon periyodundaki değișimi. Doğa Tarım ve Ormancilık, 3: 192-199.

Jackson M L (1958). Soil Chemical Analysis. Pretice-Hall, Inc. Englewood Cliffs, p: 1-498, New Jersey, U.S.A.

Kebir T, Bouhadjera K (2011). Effects of heavy metals pollution in soil and plant in the industrial area, West Algeria. Journal of the Korean Chemical Society, 55 (6): 1018-1023.

Lemee G (1967). Investigations sur la mineralisation de I'azote et son evolution annuelle dans des humus forestiers in situ. Ecologie Plant, 2: 285-324.

Lenart A, Wolny-Koładka K (2013). The effect of heavy 
metal concentration and soil $\mathrm{pH}$ on the abundance of selected microbial groups within arcelorMittal poland steelworks in Cracow. Bulletin of Environmental Contamination and Toxicology, 90(1): 85-90.

Martyn W, Skwaryło-Bednarz B (2005). Biological properties of light soils in the area of Roztocze National Park. Acta Agrophysica, 5: 695-704.

Nwuche C O, Ugoji E O (2008). Effects of heavy metal pollution on the soil microbial activity. International Journal of Environmental Science and Technology, 5: 409-414.

Obbard J P (2001). Ecotoxicological assessment of heavy metals in sewage sludge amended soils. Applied Geochemistry, 16: 1405-1411.

Reisenauer H M (1982). Chromium, in A. L. Page et al. (eds), Methods of Soil Analysis, Part 2, Chemical and Microbiological Properties, 2nd ed., Agron. Monogr. Vol. 9, ASA and SSSA, Madison, WI, U.S.A., 337-346.

Sani R K, Peyton B M, Jadhyala M (2003). Toxicity of lead in aqueous medium to Desulfovibrio desulfuricans G20. Environmental Toxicology, 22 (2): 252-260.
Tecimen H B, Sevgi O (2008). Orman topraklarında mikroorganizmalar tarafından gerçekleștirilen azot dönüșümleri. SDÜ Orman Fakültesi Dergisi, cilt.A: 179-189.

Utgikar V P, Chaudhary N, Koeniger A, Tabak H H, Haines J R, Govind R (2004). Toxicity of metals and metal mixtures: Analysis of concentration and time dependence for zinc and copper. Water Research, 38 (17): 3651- 3658.

Ünver M C (2007). Murat dağı (Ușak, Kütahya) alpin ve subalpin bölgesinin bazı bitki topluluklarında azot dönüșümleri üzerinde araștırmalar. Uludağ Üniversitesi, Doktora Tezi, $116 \mathrm{~s}$.

Walpola B C, Arunakumara K K I U, Yoon M H (2011). Evaluation of nitrogen mineralization in soil polluted by zinc and cadmium. Korean Journal of Soil Science and Fertilizer, 44(4): 559-564.

Wang J, Lu Y, Shen G (2007). Combined effects of cadmium and butachlor on soil enzyme activities and microbial community structure. Environmental Geology, 51: 1221-1228. 